\title{
Hemşirelik Alanında Güçlü Bir Bilgi Merkezi: Koç Üniversitesi HemşirelikYüksek Okulu Kütüphanesi
}

\author{
A Developed Information Center in Nursing: Library \\ of the Koç University School of Nursing
}

\section{Güssün Güneş}

\begin{abstract}
Öz
Bu makalede, Koç Üniversitesi Hemşirelik Yüksek Okulu Kütüphanesi'nin kuruluşu, koleksiyon yapısı, sunulan hizmetler ve Türkiye'de hemşireliğin profesyonel gelişimi için kurulmuş bir branş kütüphanesi olarak öneminden bahsedilecektir.
\end{abstract}

Anahtar sözcükler: Koç Üniversitesi Hemşirelik Yüksek Okulu Kütüphanesi, Üniversite Kütüphaneleri, Hemşirelik Kütüphaneleri, kütüphane hizmetleri, kütüphane tanıtımı.

\begin{abstract}
This paper describes the foundation and development of the Koc University School of Nursing Library. Main explanations were about the collection structure and user services provided, through which the importance of a special library for the professional development of nursing in Turkey has also been stressed upon
\end{abstract}

Keywords: Library of the Koç University School of Nursing, University libraries, Nursing libraries, Library publicity, Library services.

‘Sağlık Bilimleri Kütüphanecisi, Koç Üniversitesi Hemşirelik Yüksek Okulu Kütüphanesi (ggunes@ku.edu.tr) 


\section{Giriş}

Koç Üniversitesi Hemşirelik Yüksek Okulu Kütüphanesi (HYO), Koç Üniversitesi Suna Kıraç Kütüphanesi'nin hemşirelik bilimi üzerine yoğunlaşmış bir birim kütüphanesidir. Kütüphane üniversitenin öğrencileri, öğretim görevlileri, personeli, SANERC (Semahat Arsel Hemşirelik Eğitim ve Araştırma Merkezi) kursiyerleri, Amerikan Hastanesi hemşire, doktor ve diğer çalışanlarının bilgi intiyaçlarını karşılamak amacıyla Ekim 1999'da açılmıştır. 2001-2002 akademik yılında taşındığı Nişantaşı Güzelbahçe Sokak No:20 D-Blok'taki yeni binasında, modern yapısı, teknolojik donanımı, güncel bilgi kaynakları, çağdaş hizmet anlayışı ve uzman kütüphanecileri ile hemşirelik alanında bilimsel bilgiye erişimde Türkiye'nin konusal anlamda hizmet veren en iyi "Hemşirelik Kütüphanesi" olmuştur. Kütüphane, sadece kendi kullanıcılarına değil, tüm Türkiye'den ve dünyadan hemşirelik alanında araştırma yapan kullanıcılara da ücret talep etmeksizin bazı hizmetler sunmaktadır.

Kütüphanenin amacı, Kütüphane'ye gelen kullanıcının hemşirelik ve sağıık bilimleri alanlarında bilgi intiyacını tam ve hızlı bir şekilde karşılamaktır. Kullanıcının araştırma konusuna uygun kaynakları bulma, bibliyografik bilgi problemlerini giderme, İnternet üzerinden erişilebilen çevrimiçi katalogun (http://library.ku.edu.tr) ve elektronik bilgi kaynaklarının kullanılmasına yardımcı olmak uzman kütüphanecilerinin temel görevleri arasındadır. Uzman kütüphaneciler aynı zamanda kütüphane kaynak ve hizmetlerinin tanıtımını yapmak üzere düzenli olarak uyum ve eğitim programları hazırlayıp, sunmaktadırlar.

Kütüphane'deki temel koleksiyon öncelikle üniversitenin öğretim programını, öğrenci ve öğretim görevlilerinin araştırma konularını desteklemekte ve ağırıklı olarak hemşirelik ve sağlık bilimleri kaynaklarından oluşmaktadır. Kütüphane koleksiyonu rezerv, referans ve genel koleksiyon olmak üzere üç bölüm altında raflara yerleştirilmiştir. Genel konularla ilgili materyallerin sınıflama sistemi Library of Congress Sınıflama Sistemi'ne göre, sağlık alanı ile ilgili materyallerin sınıflandırılması ise National Library of Medicine Sınıflama Sistemi'ne göre yapılmakta ve bütün kaynaklar açık raflarda kullanıcıların hizmetine sunulmaktadır. 


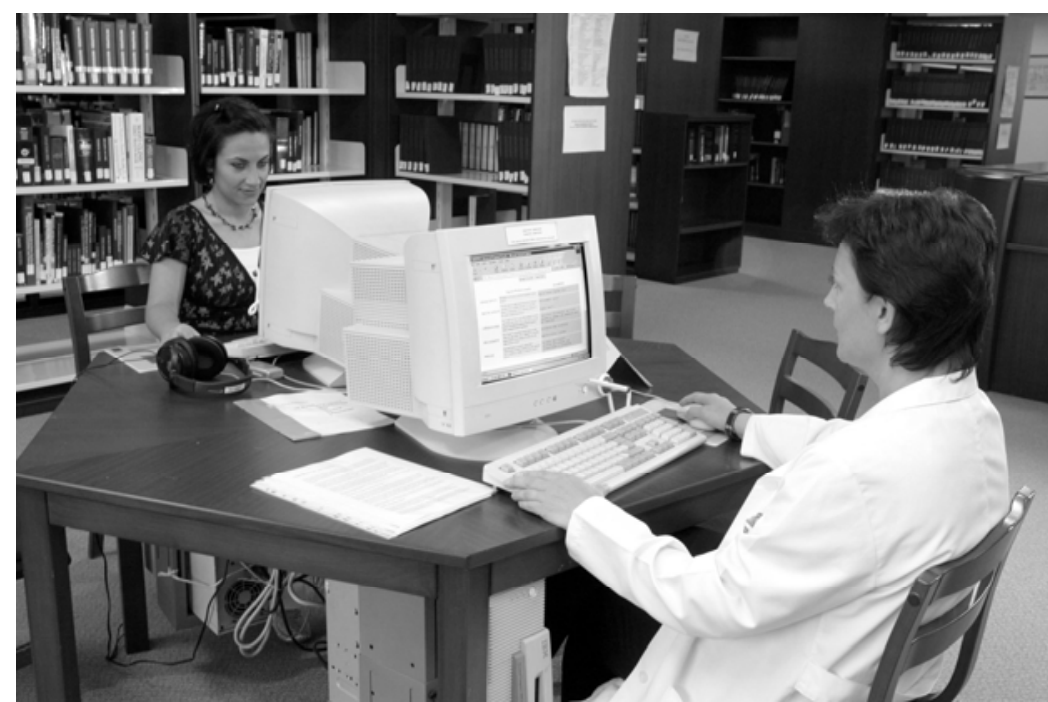

Koç Üniversitesi Hemşirelik Yüksek Okulu Kütüphanesi OPAC Terminali

Kütüphane'nin web üzerinden erişebilen kanıta dayalı, hasta bakım ve klinik uygulamaları içeren akademik ve bilimsel içerikli birçok veri tabanına aboneliği bulunmaktadır. Kütüphane koleksiyonunda; hemşirelik, tıp ve sağlık konularında 9000 başlıktan fazla materyal bulunmaktadır. Hemşirelik ve sağlık bilimi koleksiyonundaki kitaplar, dünyada ve Türkiye'de yayınlanmış en güncel baskılardan oluşmaktadır.

Kütüphane'de Türkçe ve İngilizce bilimsel 52 adet basılı ve 2000'nin üzerinde elektronik süreli yayın izlenmektedir. Basılı dergilerin son sayıları açık raf sistemi ile raflarda bulunmakta ve sadece kütüphane içinde kullanılmaktadır. Dergilerin ciltli sayıları genel koleksiyonun içinde yer almakta ve kitap gibi ödünç alınabilmektedir.

Ayrıca hemşirelik ve sağlık alanı ile ilgili olarak 1200'den fazla dvd, video kaset, cd-rom, ses kaseti, disket ve dia bulunmakta, beş adet Türkçe gazete ile bir adet yabancı gazete de düzenli olarak satın alınmaktadır.

Kütüphane'nin ödünç verme politikaları, eğitim ve araştırma amaçlı olarak kaynakların en verimli şekilde kullandırımasını sağlamayı amaçlamaktadır. Danışma kaynakları, rezerv 
kaynakları, süreli yayınların ciltlenmemiş sayıları ve görsel-işitsel materyaller dışındaki tüm kütüphane kaynakları ödünç alınabilmektedir. Kütüphane'ye üye olmayan kullanıcılar, kütüphane kaynaklarından kütüphane içinde yararlanabilmekte ancak ödünç materyal alamamaktadırlar.

Tüm kullanıcılar kütüphanede bulunan altı OPAC terminalini kullanabilirler. Bütün kaynakların bibliyografik bilgilerine İnternet üzerindeki katalogdan erişmek mümkündür. Kullanıcılar ayrıca Internet sitelerini araştırıp, bilgisayar çıktısı alabilirler.

Kullanıcılar kütüphane içinde bulunan fotokopi makinesi ve bilgisayar yazıcısından ücret karşılığında faydalanabilmektedirler.

Kütüphane'nin açılış-kapanış saatleri okulun öğretim yılına göre düzenlenmektedir.

Pazartesi-Perşembe-

09:00 - 21:00

Cuma

09:00 - 18:00

Cumartesi

Kapalı

Pazar

11:00 - 17:00

Saatlerdeki bu uygulama tatillerde ve öğretim yılı sonunda değişmektedir.

HYO Kütüphanesi'nin erişim bilgileri:

Koç Üniversitesi Hemşirelik Yüksekokulu Kütüphanesi

Güzelbahçe Sk. No:20 D-Blok

34365 Nişantaşı-İstanbul

Tel: 0-212-311 26 23-3112620

Faks: 0-212-311 2621 